\title{
ASSOCIATION STUDY OF GENETIC VARIANTS IN THE 14q11 - 14q13 PROTEASOMAL GENES CLUSTER WITH JUVENILE IDIOPATHIC ARTHRITIS (JIA) IN LATVIAN POPULATION
}

\author{
Ilva Trapina ${ }^{*, * *}$, Ingrīda Rumba-Rozenfelde**, Nikolajs Sjakste**,***, \\ Jelizaveta Sokolovska ${ }^{\star, * *, * \star *}$, Olga Sugoka*, and Tatjana Sjakste* \\ * Institute of Biology, University of Latvia, Miera iela 3, Salaspils, LV-2169, LATVIA; \\ e-mail: ilva.trapina@lu.Iv \\ ${ }^{* *}$ Faculty of Medicine, University of Latvia, Šarlotes iela 1a, Rīga, LV-1001, LATVIA \\ *** Latvian Institute of Organic Synthesis, Aizkraukles iela 21, Rīga, LV-1006, LATVIA
}

Communicated by Andrejs Ërglis

The possible role of proteasomes in the development of autoimmune diseases was hypothesised after discovery of the involvement of proteasomal LMP2 and LMP7 subunits in antigene processing. The objective of this study was to determine the association between allelic variants of the genes encoding proteasomal proteins PSME1, PSME2 and PSMA6 and juvenile idiopathic arthritis (JIA) in the Latvian population. One Indel $G^{-4543} C A^{-4544} \rightarrow G A$ and four SNPs related to the PSMA6 gene $\left(A^{-2486} \rightarrow G\right.$ and $C^{-1910} \rightarrow T$, upstream promoter, $C^{-110} \rightarrow A$ of promoter, and $C^{-8} \rightarrow G$ of $\left.5^{\prime} \cup T R\right)$, of two CSNP in PSME1 $\left(G^{1457} \rightarrow A: V a^{104}\right.$, exon 6 and $C^{2536} \rightarrow A: L y s^{244} \rightarrow T h r$, exon 11) and in PSME2 ( $C^{1153} \rightarrow G:$ Arg $^{61} \rightarrow G l y$, exon 4 and $A^{1440} \rightarrow C: H i S^{89} \rightarrow$ Pro, exon 6) were genotyped by means of primer-specific PCR, CAPS assay and/or sequencing in case/control study composed from the 156 JIA patients and 214 healthy individuals. Allele frequency and genotype distribution was similar in cases and controls for Indel, and SNPs $A^{-2486} \rightarrow G, C^{-1910} \rightarrow T$ and $C^{-8} \rightarrow G$ of PSMA6, as well as for all studied cSNPs in PSME1 and PSME2 genes. Differences in $A^{-110}$ allele and CG genotype frequencies were close to the statistically significant $P$ level in JIA patients and healthy individuals, however, when an additive model was applied, the difference in the $C^{-110} \rightarrow A$ locus turned out to be statistically significant. The results support the hypothesis of the possible association of PSMA6 gene allelic variants with JIA in the Latvian population.

Key words: PSMA6, chromosome 14, SNP polymorphism, juvenile idiopathic arthritis, association study.

\section{INTRODUCTION}

Juvenile idiopathic arthritis (juvenile rheumatoid arthritis, JIA) is the most prevalent paediatric rheumatic diagnosis among children in many countries (Glass and Giannini, 1999). JIA is a clinically heterogeneous group of phenotypes that have in common chronic inflammatory synovitis in children under the age of 16 (Prahalad et al., 2001). Seven subtypes of JIA, based on the clinical characteristics at onset are distinguished; including the more frequent oligo, poly, psoriatic and systemic JIA variants (Petty at al., 2004). The genetic contributions to disease risk have been observed in many case/control studies (Glass and Giannini, 1999; Prahalad et al., 2001). A genome scan revealed linkage of JIA to the HLA region, additional evidence supporting linkage of JIA was observed at 1p36, 19p13, and 20q13 (Thompson et al., 2004). However, the low odds ratios for most individual "JIA risk alleles" suggest that gene-gene interactions, which are poorly described or understood at present, likely influence whether pathology develops (Glass and Giannini, 1999). This consideration encourages extension of the search for JIA candidate genes.

The chromosome 14q region appears to be prospective for the above goal, as it harbours several genes of interest. Linkage of the locus to autoimmune diseases has been already reported (John and Worthington, 2001). Possible candidate genes include the genes encoding the nuclear factor kappa B inhibitor (NFKBI) on 14q13 (le Beau et al., 1992), the transcription factor FOS on 14q23, TGF-beta3 on $14 \mathrm{q} 24$, and immunoglobulin heavy chain locus at $14 \mathrm{q} 32.33$ (Kamnasaran and Cox, 2002). Several proteasomal genes are located at $14 \mathrm{q}$ including proteasomal activator subunits 1 and 2 (PSME1 and PSME2, respectively) and proteasome 
subunit of beta type 5 (PSMB5) at $14 q 11.2$, proteasome subunits of alpha type 6 (PSMA6) at $14 \mathrm{q} 13$, and alpha type 3 (PSMA3) at 14q23 (Chistyakov et al., 2000).

The proteasome is a multisubunit enzyme complex which plays a central role in the degradation of proteins controlling transcription rate, cell-cycle progression and apoptosis; therefore, an important role in pathogenesis of human diseases has been ascribed to the structure (Glickman et al., 2001; Almond et al., 2002; Naujokat et al., 2002; Sjakste et al., 2002a; 2002b). To a known extent, proteasomes interfere also with the atherogenesis process. Proteasomes degrade $I F-\kappa B$ factor with subsequent activation of the

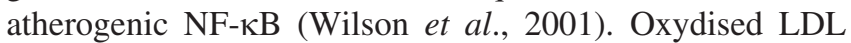
causes activation of the proteasome activity followed by decline of this activity. HDL is an inhibitor of the proteasome activity (Vieira et al., 2000; Robbesyn et al., 2003).

The latter gene group appears to be of special interest as it was shown that the proteasomal protein LMP2 gene polymorphism affects the susceptibility to, and severity of HLA-B27 associated juvenile idiopathic arthritis (Pryhuber et al., 1996).

We have previously addressed the possible association of the PSMA6 gene in the genetic susceptibility to various diseases. The PSMA6 gene is encoded by a single-copy gene on chromosome 14q13.2 between markers D14S960 and D14S889 (Sjakste et al., 2001). In the initial studies we investigated a microsatellite polymorphism in intron 6 of the gene in several human populations (Sjakste et al., 2002c). Further studies showed that this marker is associated with Graves' disease (Sjakste et al., 2004) and diabetes mellitus type 2 (DM2, Kalis et al., 2002; Sjakste et al., 2007a). Genotyping of the single nucleotide polymorphism (SNP) in the promoter and 5'-UTR region of the PSMA6 gene, resulted in the discovery of the association of the genotype $-8 \mathrm{C} / \mathrm{G}$ and haplotype $\mathrm{C}^{-110} / \mathrm{G}^{-8}$ with a higher risk of DM2 (Sjakste et al., 2007b).

In this study we investigated whether chromosome $14 \mathrm{q}$ region SNP is associated with increased risk of juvenile idiopathic arthritis.

\section{MATERIALS AND METHODS}

Case/control study description. The polymorphisms were genotyped in a case/control study of 156 juvenile idiopathic arthritis patients and 214 subjects without JIA from the Latvian population. The case group (63\% females) consisted of patients attending the outpatient clinic at the Pauls Stradiňs Clinical University Hospital and the Children's Hospital "Gailezers". The group represented about $60 \%$ of all registered in Latvia JIA patients. Patients ( $57 \%$ females) to the Rìga Biķernieki Hospital specialised in trauma medicine, were recruited to participate in the study control group (without autoimmune diseases). Informed consent was obtained from all patients; the study was approved by the Central Medical Ethics Commission of the Latvian Medical Academy.
DNA extraction was performed using a kit for genomic DNA extraction from nucleated blood cells (Fermentas, Vilnius, Lithuania). DNA quantity and quality was determined by electrophoresis in agarose gel.

Genotyping of 6 SNP including $\mathrm{G}^{1457} \rightarrow \mathrm{A}$ and $\mathrm{C}^{2536} \rightarrow \mathrm{A}$ of PSME1; $\mathrm{C}^{1153} \rightarrow \mathrm{G}$ and $\mathrm{A}^{1440} \rightarrow \mathrm{C}$ of PSME2; and $\mathrm{A}^{-2486} \rightarrow \mathrm{G}$ and $\mathrm{C}^{-8} \rightarrow \mathrm{G}$ of PSMA6 was conducted by MALDI-TOF Mass Spectrometry approach (Wenzel et al., 2003) on a MALDI TOF Autoflex Bruker Daltonics using genoSNIP specific primers (Table 1). One base pair insertion/deletion polymorphism (InDel) $\mathrm{G}^{-4543} \mathrm{CA}^{-4544} \rightarrow \mathrm{GA}$ and SNP C ${ }^{-1910} \rightarrow$ T were genotyped by CAPS (cleaved amplified polymorphism) assay using correspondingly BseMI and EcoNI restriction sites in the intergenic region upstream PSMA6 gene. SNP $\mathrm{C}^{-110} \rightarrow \mathrm{A}$ (PSMA6 promoter) was analysed by allele specific PCR. Information on the primer sequences, amplified and restricted fragment sizes, SNPs GenBank accession numbers, and function of the polymorphism is given in Table 1.

PCR was performed in a final volume of $30 \mu \mathrm{l}$ containing around $100 \mathrm{ng}$ genomic DNA, 10× DreamTag polymerase buffer (final concentration $1 \times$ ), $25 \mathrm{mM} \mathrm{MgCl}_{2}$ (from 1.5 $\mathrm{mM}$ to $3 \mathrm{mM}), 10 \mathrm{mM}$ dNTP Mix $(0.5 \mathrm{mM}), 10 \mathrm{pM}$ forward and reversal primers $(0.33 \mathrm{pM}$ each) and 0.75 units of DreamTaq polymerase (Fermentas, Vilnius, Lithuania). PCR denaturation at $95{ }^{\circ} \mathrm{C} 5 \mathrm{~min}$ was followed by 35-40 cycles each of $30 \mathrm{sec}$ of denaturation at $95{ }^{\circ} \mathrm{C}, 30 \mathrm{~s}$ of annealing (at $55-63^{\circ} \mathrm{C}$ depending on the polymorphism analysed) and $60 \mathrm{~s}$ of extension at $72{ }^{\circ} \mathrm{C}$, with final extension step of $7 \mathrm{~min}$ at $72{ }^{\circ} \mathrm{C}$. PCR products were tested by electrophoresis in $1 \%$ agarose gel. Allele specific PCR was performed using allele specific forward primers differing only in the 3'-end polymorphic nucleotide and the reversal primer common for both alleles (Table 1). Presence or absence of the amplified product directly indicated the presence or absence of the corresponding allele. PCR product was digested in case of CAPS assay by the corresponding restriction enzyme. Digestion was performed in final volume of $25 \mu \mathrm{l}$ containing about $1,000 \mathrm{ng}$ of DNA in PCR product, $10 \times$ Buffer $\mathrm{R}$ (final concentration $1 \times$ ) and 0.5 units of the corresponding restriction enzyme (Fermentas, Vilnius, Lithuania) during 2 hours at $55{ }^{\circ} \mathrm{C}$ or $37{ }^{\circ} \mathrm{C}$ for BseMI or EcoNI, correspondingly. Results of the digestion were tested by gel electophoresis in $1 \%$ or $1.5 \%$ agarose gel. Fragment sizes of the digested amplicons are indicated in Table 1. Primer design was performed by the Primer 3.0 programme using the $14 q 11.2-14 q 13.2$ sequence information at the NCBI nucleotide service (GenBank accession NT_026437). Primers were synthesised in "Metabion International AG" (Germany).

SNP functionality was analysed in silico for the affinity to transcription factors (TF) using Genomatix software (DiAlign TF, Release 3.1, and MatInspector, Release 7.4 tools, at http://www.genomatix.de/) and scored as loss or generation of the transcription factor binding sites (TFBS) (Fig. 1). Functionality of the coding region SNP was evaluated as amino acid substitution (Table 1). 
INFORMATION ON THE SNP, METHOD OF GENOTYPING, SEQUENCES OF THE FORWARD (F) AND REVERSAL (R) PRIMERS, AND EXPECTED FRAGMENT SIZES

\begin{tabular}{|c|c|c|c|c|c|c|}
\hline \multirow{2}{*}{$\begin{array}{c}\text { Gene / } \\
\text { chromosome } \\
\text { location }\end{array}$} & \multicolumn{3}{|c|}{ Polymorhism } & \multirow{2}{*}{$\begin{array}{l}\text { Genotyping } \\
\text { method }\end{array}$} & \multirow[t]{2}{*}{ Primers } & \multirow{2}{*}{$\begin{array}{l}\text { Fragment } \\
\text { size (bp) }\end{array}$} \\
\hline & Description & ID & Function & & & \\
\hline \multirow[t]{2}{*}{$\begin{array}{l}\text { PSME1 / } \\
14 \mathrm{q} 11.2\end{array}$} & $\mathrm{G}^{1458} \rightarrow \mathrm{A}$ & rs11574508 & $\begin{array}{c}\text { Exon } 6 \\
\text { Val }^{104} \rightarrow \text { Val }\end{array}$ & genoSNIP & $\begin{array}{l}\text { F: 5'-CACACAGGCTCAATCATGT - 3' } \\
\text { R: 5'-GACTTGAAGCCTGAGAGTTT - 3' } \\
\text { 5'- TCCTCCCTGLGGCCCAGT - 3' } \\
\text { 5'- TCCTCCCTGLGGCCCAGTG - 3' } \\
\text { 5'- TCCTCCCTGLGGCCCAGTAAACTG - 3', }\end{array}$ & 179 \\
\hline & $\mathrm{C}^{2536} \rightarrow \mathrm{A}$ & rs 14930 & $\begin{array}{c}\text { Exon } 11 \\
\text { Lys }^{244} \rightarrow \text { Thr }\end{array}$ & genoSNIP & $\begin{array}{l}\text { F: 5'- ACGTTGGATGGCCCTGTAGGCTGTGTTAT - 3' } \\
\text { R: 5'-ACGTTGGATGCCACTCCCTCTACCTCTTCT - 3' } \\
\text { 5'- biotin-CAAGAAGCCLAGGGGAGAAA-3' }\end{array}$ & 264 \\
\hline \multirow[t]{2}{*}{$\begin{array}{l}P S M E 2 / \\
14 \mathrm{q} 11.2\end{array}$} & $\mathrm{C}^{1153} \rightarrow \mathrm{G}$ & rs1136581 & $\begin{array}{c}\text { Exon } 4 \\
\text { Gly }^{61} \rightarrow \text { Arg }\end{array}$ & genoSNIP & $\begin{array}{l}\text { F: 5'-AGGCATGAGCCTAGGTTG - 3' } \\
\text { R: 5'-GAGGTTGAAGGGCTATCTT - 3' } \\
\text { 5'- GGCTGACTTGACTLCCCTC - 3' } \\
\text { 5'-GGCTGACTTGACTLCCCTCG - 3' } \\
\text { 5'-GGCTGACTTGACTLCCCTCCG - 3' }\end{array}$ & 263 \\
\hline & $\mathrm{A}^{1430} \rightarrow \mathrm{C}$ & rs7146672 & $\begin{array}{c}\text { Exon } 6 \\
\text { Pro }^{89} \rightarrow \text { His }\end{array}$ & genoSNIP & $\begin{array}{l}\text { F: 5'- GGGTGATGGCACACTGAC - 3' } \\
\text { R: 5'-AATGCATTTCTCTTTGAGAGT - 3' } \\
\text { 5'-CAGGGAGAALTCCACACTTA - 3' } \\
\text { 5'-CAGGGAGAALTCCACACTTAT - 3' } \\
\text { 5'-CAGGGAGAALTCCACACTTAGGGACT - 3' }\end{array}$ & 153 \\
\hline \multirow[t]{5}{*}{$\begin{array}{l}\text { PSMA6 / } \\
14 \mathrm{q} 13.2\end{array}$} & $\mathrm{G}^{-4543} \mathrm{CA}^{-4544} \rightarrow \mathrm{GA}$ & rs5807825 & $\begin{array}{l}\text { Intergenic } \\
\text { region }\end{array}$ & $\begin{array}{l}\text { CAPS } \\
\text { BseMI }\end{array}$ & $\begin{array}{l}\text { F: 5'- GTCCTCAGGGAGGAAGCTCT - 3' } \\
\text { R: 5'- AGCCTGAGGTAAGCACTCCA - 3' }\end{array}$ & $\begin{array}{c}981 \\
(754+227)\end{array}$ \\
\hline & $\mathrm{A}^{-2486} \rightarrow \mathrm{G}$ & rs9322944 & $\begin{array}{l}\text { Intergenic } \\
\text { region }\end{array}$ & genoSNIP & $\begin{array}{l}\text { F: 5'- CAGAATAGCAGAGCAGGAAC - 3' } \\
\text { R: 5'- GCCAATGGGATATTTTTCAC - 3' } \\
\text { 5'-AGGGGGAGALGTATTAAGAA - 3' } \\
\text { 5'- AGGGGGAGALGTATTAAGAAA - 3' } \\
\text { 5'- AGGGGGAGALGTATTAAGAAGTTA - 3', }\end{array}$ & 211 \\
\hline & $\mathrm{C}^{-1910} \rightarrow \mathrm{T}$ & rs7493194 & $\begin{array}{l}\text { Intergenic } \\
\text { region }\end{array}$ & $\begin{array}{l}\text { CAPS } \\
\text { EcoNI }\end{array}$ & $\begin{array}{l}\text { F: 5'- TCCAGAGAAGGGTCCAGCTA - 3', } \\
\text { R: 5'-CAGGAGATCCAGGTTGCAGT - 3' }\end{array}$ & $\begin{array}{c}920 \\
(405+515)\end{array}$ \\
\hline & $\mathrm{C}^{-110} \rightarrow \mathrm{A}$ & rs2277460 & Promoter & $\begin{array}{l}\text { Allele spe- } \\
\text { cific PCR }\end{array}$ & $\begin{array}{l}\text { F: 5'-ATGCAAGAGCGGAAGAAAC - 3' } \\
\text { F: 5'-ATGCAAGAGCGGAAGAAAA - 3' } \\
\text { R: 5'-CTGAATTGCCCTGTCATGGTA - 3' }\end{array}$ & 256 \\
\hline & $\mathrm{C}^{-8} \rightarrow \mathrm{G}$ & rs1048990 & 5'-UTR & genoSNIP & $\begin{array}{l}\text { F: 5'-ACGTTGGATGCTCCAGATGAAAGCCTGA - 3' } \\
\text { R: 5'-ACGTTGGATGGCCCTATCTTCCTTAACTCTC - 3' } \\
\text { 5'- biotin-AGGGATTGTGTTTLAAGTAGTGCTT - 3' }\end{array}$ & 899 \\
\hline
\end{tabular}

Amplified and restricted sizes are indicated without and with brackets, correspondingly. Position of the polymorphic loci is numbered from the first coding ATG. MALDI-TOF Mass Spectrometry approach is denoted as genoSNIP. ID indicates GenBank polymorphic loci accession number.

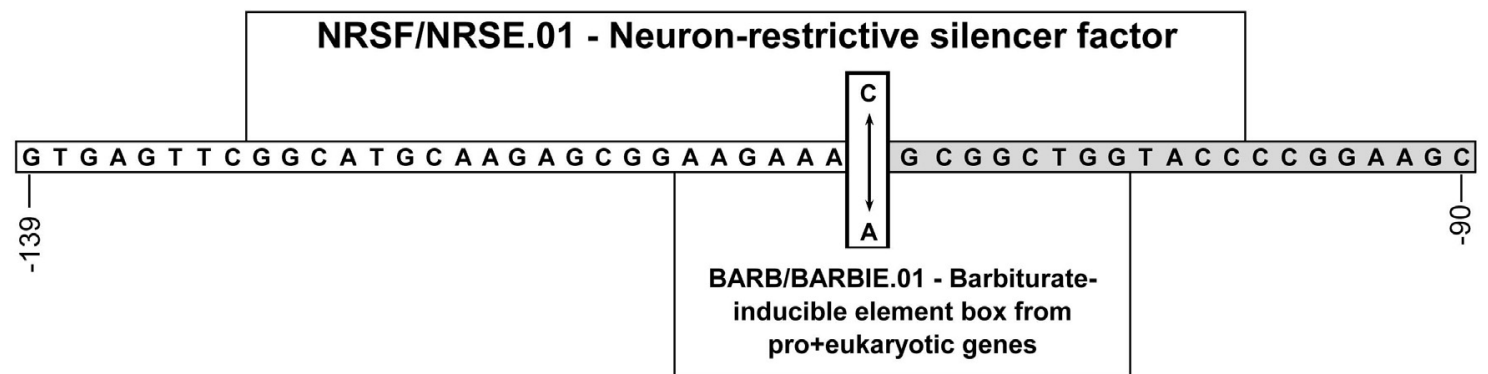

Fig. 1. Functional significance of PSMA6 SNP ${ }^{-110}$ (rs2277460). Transcription factors NRSF/NRSE.01 and BARB/BARBIE.01 occupy region from -113 to -98 and from -116 to $-102 \mathrm{nt}$, correspondingly. $\mathrm{SNP}^{-110}$ is boxed; allelic variants are indicated by a double arrow; 5 ' UTR is marked in grey. Numbering is given from the first ATG of the gene.

Data analysis. Numbers and frequencies of allele and genotype were estimated by direct gene counting. Expected heterozygocity indexes were estimated as $\mathrm{H}_{\exp }=1-\sum \mathrm{p}_{\mathrm{i}}^{2}$, where $\mathrm{p}_{\mathrm{i}}$ is the frequency of each allele at the locus. Population heterozygocity was calculated as the ratio of the number of heterozygous individuals to the total number of sub- jects. Deviations from the Hardy-Weinberg equilibrium were tested by the $\chi^{2}$ test. Significance of differences between the groups for whole loci was estimated using the $\chi^{2}$ test $\left(P_{\mathrm{a}}<0.05\right)$ following the additive model. In parallel, differences were also estimated for alleles and genotypes separately. Corrected significance levels $\left(P_{\mathrm{b}}\right)$ were calcu- 
lated by means of permutation analysis, performed using the PAST (PAlaentological Statistics, ver. 1.63) programme. Odds ratio (OR) and $95 \%$ confidence intervals were calculated using the dominant model by the MedCalc 3000 programme (http://medicalc3000.com/OddsRatio.htm).

\section{RESULTS}

Functional significance of the polymorphisms analysed is summarised in Table 1. Four SNPs related to PSME1 and PSME2 genes were located in the corresponding exons and were nonsynonymous rare mutations. Five SNPs related to PSMA6 gene were chosen for the analysis including InDel and two SNPs in 5' upstream the gene region, and SNPs at -110 position and at -8 positions from the first ATG. The latter two are of the special interest as they were located in promoter (-1 position from the 5' UTR) and in 5'UTR close to the Kozak sequence correspondingly. In silico analysis (www.genomatix.de) revealed that the sequence encom- passing SNP at -110 position possesses binding capacity to several TFs forming finally the module ETSF_SP1F_02 whose function is regulation of the gene expression by a cooperative interaction between the ubiquitously expressed factor SP1 and the lymphoid/myeloid factor PU.1. Moreover, the transition $\mathrm{C}^{-110} \rightarrow \mathrm{A}$ changes the locus affinity to two other TFs, namely to the simultaneously loss and generation of affinity to neuron-restrictive silencer factor and barbiturate-inducible element, correspondingly (Fig. 1). All SNPs chosen for the analysis were previously identified in the European population (HapMap at

http://www.hapmap.org). Recently PSMA6 gene SNPs at positions of -110 and -8 were intensively analysed for association with human disorders (Ozaki et al., 2006; Sjakste et al., 2007b, Takashima et al., 2007; Barbieri et al., 2008; Benett et al., 2008, Freilinger et al., 2009; Lui et al., 2009).

Genotyping results. Table 2 summarises data on the allele frequencies of the nine SNPs related to three proteasomal genes (Table 1). The study consisted of two genotyping

Table 2

ALLELE FREQUENCIES IN JIA CASE/CONTROL STUDY IN LATVIAN POPULATION

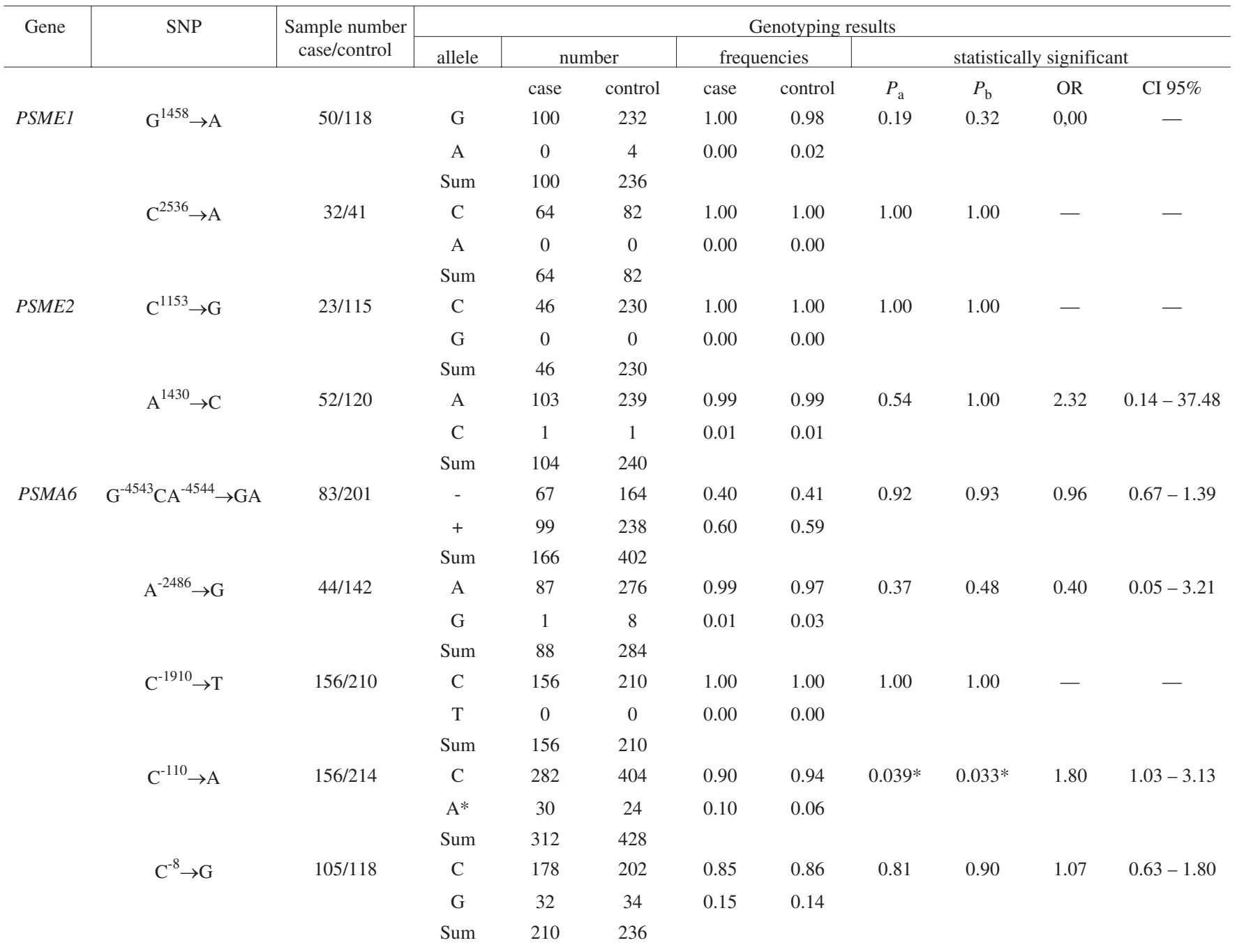

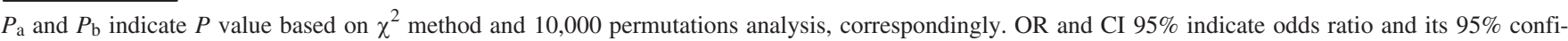
dence interval, correspondingly, only the rear allele is taken into account. Statistically significant results are marked by an asterisk. InDel alleles are shown as $(+)$ and (-) for insertion and deletion, correspondingly. 
steps including preliminary evaluation of the loci genetic diversity in the Latvian population (case group ranged from 23 to 56 individuals) and polymorphic loci genotyping for association with JIA.

Three loci including $\mathrm{C}^{2536} \rightarrow \mathrm{A}$ of $P S M E 1, \mathrm{C}^{1153} \rightarrow \mathrm{G}$ of $P S M E 2$ and $\mathrm{C}^{-1910} \rightarrow \mathrm{T}$ related to PSMA6 (5' region upstream the gene) were found to be monomorphic in Latvian population. Another three loci were slightly polymorphic $\left(\mathrm{G}^{1458} \rightarrow \mathrm{A}\right.$ of PSME1, $\mathrm{A}^{1430} \rightarrow \mathrm{C}$ of PSME2, and $\mathrm{A}^{-2486} \rightarrow \mathrm{C}$ located in 5' region upstream the PSMA6 gene) with a very low level of the rare allele presentation close to the accidental mutational rate. Loci identified as monomorphic or rare mutations were not genotyped in full JIA case/control study. Three resting loci showed higher diversity in the preliminary study and were evaluated as potentially prospective to be analysed for disease association.

Indel $\mathrm{G}^{-4543} \mathrm{CA}^{-4544} \rightarrow \mathrm{GA}$ was revealed as the most diverse locus in both groups. However, allelic frequencies did not differ between cases and controls (frequencies of deletion and insertions were about 0.4 and 0.6 in both groups). The locus at position -8 of the PSMA6 gene was presented by common $\mathrm{C}$ and rare $\mathrm{G}$ alleles of the same frequency in case and control groups.

The locus at position -110 was found to be the most interesting. Rare allele A presentation in the control group was

close to the mutational rate (frequency 0.06 ), but $1.7 \times$ more frequent in the case group (frequency 0.10). Differences in the $\mathrm{A}^{-110}$ allele and $\mathrm{CG}$ genotype frequencies were close to the statistically significant $P$ level in JIA patients and healthy individuals $\left(P_{\mathrm{a}}=0.055, P_{\mathrm{b}}=0.067\right.$, not shown), however, when an additive model was applied, the difference in $\mathrm{C}^{-110} \rightarrow \mathrm{A}$ locus was statistically significant $\left(P_{\mathrm{a}}=\right.$ $0.039, P_{\mathrm{b}}=0.033$, Table 2).

Genotypes. Taking into account the allele presentation, we can summarise that the loci at 2536 of PSME1, at 1153 of PSME2 and at -1910 of PSMA6 gene exist in a homozygous state in the Latvian population. All possible three genotypes were revealed only for InDel and SNP at -8 position of PSMA6 gene. Other loci were presented by the homozygotes on the common allele and heterozygotes (Table 3). The heterozygote CA locus at position -110 was found to be more frequent than it was reported in HapMap (0.12 and 0.02, correspondingly, for the Latvian population in average and HapMap, www.hapmap.org). It is of interest that the CA genotype at position - 110 was more than twice more frequent in the JIA case group compared to healthy individuals (frequency 0.19 and 0.08 , correspondingly) with a $P$ value close to the statistically significant level $\left(P_{\mathrm{a}}=\right.$ $0.064, P_{\mathrm{b}}=0.077$; not shown). Application of the additive model for the locus $\mathrm{C}^{-110} \rightarrow \mathrm{A}$ genotypes revealed statistically significant differences between the groups $\left(P_{\mathrm{a}}=\right.$

Table 3

GENOTYPE FREQUENCIES IN JIA CASE/CONTROL STUDY IN LATVIAN POPULATION

\begin{tabular}{|c|c|c|c|c|c|c|c|c|c|c|}
\hline \multirow[t]{2}{*}{ Gene } & \multirow[t]{2}{*}{ SNP } & \multicolumn{9}{|c|}{ Genotyping results } \\
\hline & & genotype & \multicolumn{2}{|c|}{ number } & \multicolumn{2}{|c|}{ frequencies } & \multicolumn{4}{|c|}{ statistically significant } \\
\hline & & & case & control & case & control & $P_{\mathrm{a}}$ & $P_{\mathrm{b}}$ & OR & CI $95 \%$ \\
\hline \multirow[t]{3}{*}{ PSME1 } & $\mathrm{G}^{1458} \rightarrow \mathrm{A}$ & GG & 51 & 114 & 1.00 & 0.97 & 0.18 & 0.31 & 0,00 & - \\
\hline & & GA & 0 & 4 & 0.00 & 0.03 & & & & \\
\hline & & Sum & 51 & 118 & & & & & & \\
\hline \multirow[t]{3}{*}{ PSME2 } & $\mathrm{A}^{1430} \rightarrow \mathrm{C}$ & $\mathrm{CC}$ & 52 & 119 & 0.99 & 0.98 & 0.55 & 1.00 & 2.28 & $0.14-37.29$ \\
\hline & & $\mathrm{CA}$ & 1 & 1 & 0.01 & 0.02 & & & & \\
\hline & & Sum & 53 & 120 & & & & & & \\
\hline \multirow[t]{14}{*}{ PSMA6 } & $\mathrm{G}^{-4543} \mathrm{CA}^{-4544} \rightarrow \mathrm{GA}$ & -- & 11 & 30 & 0.13 & 0.15 & 0.91 & 0.92 & 1.04 & $0.60-1.79$ \\
\hline & & -+ & 45 & 104 & 0.54 & 0.52 & & & & \\
\hline & & ++ & 27 & 67 & 0.33 & 0.33 & & & & \\
\hline & & Sum & 83 & 201 & & & & & & \\
\hline & $\mathrm{A}^{-2486} \rightarrow \mathrm{G}$ & $\mathrm{AA}$ & 43 & 134 & 0.98 & 0.94 & 0.36 & 0.45 & 0,39 & $0.05-3.20$ \\
\hline & & AG & 1 & 8 & 0.02 & 0.06 & & & & \\
\hline & & Sum & 44 & 142 & & & & & & \\
\hline & $\mathrm{C}^{-110} \rightarrow \mathrm{A}$ & $\mathrm{CC}$ & 126 & 190 & 0.81 & 0.92 & $0.031 *$ & $0.023^{*}$ & 1,88 & $1.05-3.37$ \\
\hline & & $\mathrm{CA}^{*}$ & 30 & 24 & 0.19 & 0.08 & & & & \\
\hline & & Sum & 156 & 214 & & & & & & \\
\hline & $\mathrm{C}^{-8} \rightarrow \mathrm{G}$ & $\mathrm{CC}$ & 75 & 87 & 0.71 & 0.73 & 0.85 & 0.88 & 1.16 & $0.64-2.10$ \\
\hline & & $\mathrm{CG}$ & 28 & 28 & 0.27 & 0.24 & & & & \\
\hline & & GG & 2 & 3 & 0.02 & 0.03 & & & & \\
\hline & & Sum & 105 & 118 & & & & & & \\
\hline
\end{tabular}

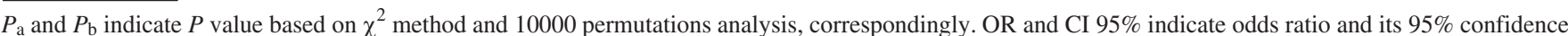
interval, correspondingly, only genotypes having at least one rare allele are taken into account. Statistically significant results are marked by an asterisk. InDel alleles are shown as (+) and (-) for insertion and deletion, correspondingly. 
$0.031, P_{\mathrm{b}}=0.028, \mathrm{OR}=1.88$ with $95 \%$ confidence interval ranging from 1.05 to 3.37 ).

\section{DISCUSSION}

We present here the results of an association study between proteasomal gene polymorphism and JIA in the Latvian population. Proteasomal genes were chosen as gene candidates, taking into account the hypothetical importance of defective proteasomal protein degradation in the pathogenesis of the disease (Deng et al., 1995; Maksymowicz and Russel, 1995; Pryhuber et al., 1996; Heward et al., 1999; Sjakste et al., 2004). We have focussed our attention on three highly evolutionary conserved genes located in the long arm of chromosome 14 including PSME1, PSME2 and PSMA6 encoding proteasomal activator proteins PSME1 and PSME2 and the proteasomal alpha subunit PSMA6, correspondingly. Nine SNPs were genotyped, including four of PSME1 and PSME2 coding regions and five of PSMA6 non-coding region variations. High conservatism of the PSMA6 coding gene region was proved in our previous study (Sjakste et al., 2007a). We confirmed here low genetic diversity of the proteasomal genes as coding as well noncoding gene regions. Two PSMA6 gene SNPs, including those at positions -110 and -8 from the first ATG located in gene promoter and 5'UTR, correspondingly, were of special interest because of their higher level of polymorphism and previously postulated and suggested association to several human disorders (Ozaki et al., 2006; Sjakste et al., 2007b; Takashima et al., 2007; Barbieri et al., 2008; Benett et al., 2008; Freilinger et al., 2009; Lui et al., 2009). PSMA6 SNP at position -8 is interesting because of its suggested functionality due to location close to the Kozak sequence and possible interference with the initiation of the translation. Some diseases are caused by mutations that perturb the initiation step of translation by changing the context around the $\mathrm{AUG}^{\text {start }}$ codon or introducing upstream AUG codons (Kozak, 2002; Kozak, 1997). The context around the initiation codon of the PSMA6 gene (ACCAACaugT) does not represent classical "Kozak" consensus in the +4 position, where G is preferred (Kozak, 1997). Occurrence of the "good" (ANNaugN) but not "perfect" (ANNaugG) context
(Kozak, 2002) might increase the possible influence of mutations in the 5'- and 3'-areas from the consensus on the perturbation of the translation initiation. Using several models and approaches, Ozaki and colleagues (2006) reported that the allele $\mathrm{G}$ showed approximately 1.5 - to 1.8 -fold higher gene expression compared to the $\mathrm{C}$ allele and that the $\mathrm{G}$ allele could bind unknown nuclear factor(s) to exon 1 of PSMA6. Taken this into account, this variation was genotyped very intensively in different populations, especially in respect to the association with cardiovascular disorders (Ozaki et al., 2006; Sjakste et al., 2007b; Takashima et al., 2007; Barbieri et al., 2008; Benett et al., 2008; Freilinger et al., 2009; Lui et al., 2009) and DM2 (Sjakste et al., 2007b; Barbieri et al., 2008). Results on the rare allele association with myocardial infarction (MI) are still controversial (Fig. 2), however, statistically significant data were obtained in favour of its association with DM2 (Sjakste et al., 2007b, Barbieri et al., 2008; Fig. 2). Data summarised in Figure 2 clearly demonstrate that, firstly, the $\mathrm{SNP}^{-8}$ allelic distribution is similar between the Latvian and other European and Asian populations and secondly, that there is no association between locus variation and JIA in the Latvian population.

The most prospective result was obtained for PSMA6 SNP at position -110 . We have shown significant differences for locus $\mathrm{C}^{-110} \rightarrow \mathrm{A}$ and a borderline association between its rare allele and heterozygous genotype frequencies and JIA in the Latvian population. Previously, a borderline association between the rare $\mathrm{A}^{-110}$ allele and DM2 was revealed in the Latvian population (Sjakste et al., 2007b). It should be stressed that in current and in previous studies (Sjakste $e t$ al., 2007b) in both Latvian and UK populations we did not reveal homozygotes for the rare allele, this is an additional indication on the negative role of this allele. In silico analysis revealed that the $\mathrm{SNP} \mathrm{C}^{-110} \rightarrow \mathrm{A}$ transition is followed by the loss of locus affinity to TF belonging to neuron-restrictive silencer factor family and simultaneously to the generation of binding capacity to barbiturate-inducible element. Both allelic variants of the sequence encompassing SNP at -110 position possess binding capacity to several TFs that form finally the module ETSF_SP1F_02, whose function is regulation of the gene expression by a cooperative interac-

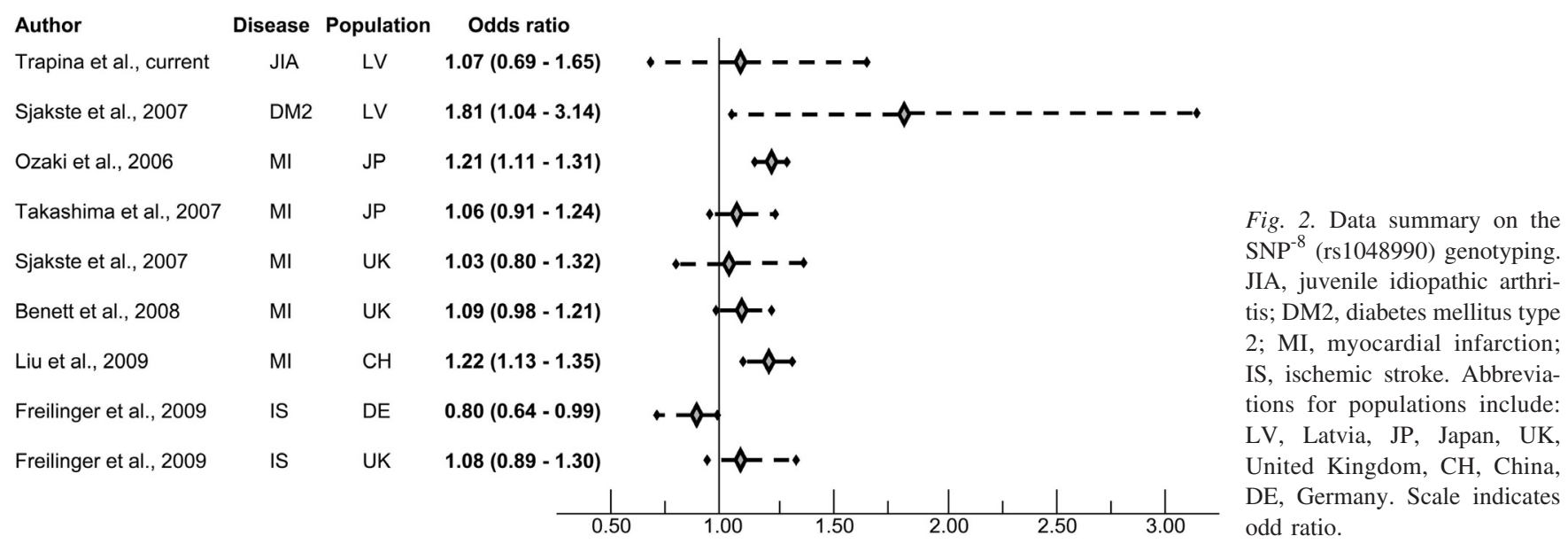


tion between the ubiquitously expressed factor SP1 and the lymphoid/myeloid factor PU.1. Further progress in our knowledge of the molecular processes of the genome regulation could reveal more consequences of this variation.

The results obtained in the study are in agreement with hypothesis on the association of PSMA6 gene polymorphism and JIA and need further increased case/control study.

\section{ACKNOWLEDGEMENTS}

The work was supported by the National Research Programme in Medicine 2006-2009, project No. 5, „Elaboration of modern approaches on early diagnostics, prevention and treatment of diseases affecting mortality and chronic morbidity of children", and partly by grant of the Latvian Council of Science No. 05.1399, "Association of the polymorphism of Chromosome 14 molecular markers with human pathologies", attributed to T.S. I.T. is indebted to ESF programme of the European Community for fellowship. Figure design performed by Natalia Paramonova is greatly appreciated.

\section{REFERENCES}

Almond, J.B., Cohen, G.M. (2002). The proteasome: A novel target for cancer chemotherapy. Leukemia, 18, 433-443.

Barbieri, M., Marfella, R., Rizzo, M.R., Boccardi, V., Siniscalchi, M., Schiattarella, C., Siciliano, S., Lemme, P., Paolisso, G. (2008). The -8 UTR C/G polymorphism of PSMA6 gene is associated with susceptibility to myocardial infarction in type 2 diabetic patients. Atherosclerosis, 201(1), $117-123$.

le Beau, M.M., Ito, C., Cogswell, P., Espinosa, R. 3d., Fernald, A.A., Baldwin, A.S. (1992). Chromosomal localization of the genes encoding the p50/p105 subunits of Nf-kappa B (NFKB2) and the I kappaB/MAD-3 (NFKBI) inhibitor of NF-kappa B to $4 \mathrm{q} 24$ and $14 \mathrm{q} 13$, respectively. Genomics, 14, 529-531.

Bennett, D.A., Xu, P., Clarke, R., Zondervan, K., Parish, S., Palmer, A., Cardon, L., Peto, R., Lathrop, M., Collins, R. (2008). The exon 1-8C/G SNP in the PSMA6 gene contributes only a small amount to the burden of myocardial infarction in 6946 cases and 2720 controls from a United Kingdom population. Eur. J. Hum. Genet., 16, 480-486.

Chistyakov, D.A., Savostanov, K.V., Turakulov, R.I., Nosikov, V.V. (2000). Genetic determinants of Graves disease. Mol. Genet. Metab., 71, 66-69.

Deng, G.Y., Muir, A., Maclaren, N.K., She, J.X. (1995). Association of LMP2 and LMP7 genes within the major histocompatibility complex with insulin-dependent diabetes mellitus: Population and family studies. Amer. J. Hum. Genet., 56, 528-534.

Freilinger, T., Bevan, S., Ripke, S., Gschwendtner, A., Lichtner, P., MüllerMyhsok, B., Wichmann H.-E., Markus, H.S., Meitinger, T., Dichgans, M. (2009). Genetic variation in the lymphotoxin-alpha pathway and the risk of ischemic stroke in European populations. Stroke, 40, 970-972.

Glass, D.N., Giannini, E.H. (1999). Juvenile rheumatoid arthritis as a complex genetic trait. Arthritis Rheum., 42(11), 2261-2268.

Glickman, M., Ciechanover, A. (2001). The ubiquitin-proteasome proteolytic pathway: Destruction for the sake of construction. Physiol. Rev., 82, 373-428.

Heward, J.M., Allhabadia, A., Sheppard, M.C., Barnett, A.H., Franklyn, J.A., Gough, S.C. (1999). Association of the large multifunctional proteasome (LMP2) gene with Graves disease is a result of linkage disequilibrium with the HLA haplotype DRB1*034-DQB1*02-DQA1*0501. Clin. Endocrinol. $(O x f), \mathbf{5 1}, 115-118$.
John, S., Worthington, J. (2001). Genetic epidemiology. Approaches to the genetic analysis of rheumatoid arthritis. Arthritis Res., 3, 216-220.

Kalis, M., Sjakste, T., Sjakste, N., Luthman, H., Groop, L. (2002). Association study between (TG) repeat polymorphism in PSMA6 gene and type II dibetes mellitus in Botnia. Biologija, 2, 12-14.

Kamnasaran, D., Cox, D.W. (2002). Current Status of Human Chromosome 14. J. Med. Genet., 39, 81-91.

Kozak, M. (1997). Recognition of AUG and alternative initiator codos is augmented by $\mathrm{G}$ in position +4 but is not generally affected by the nucleotides in positions +5 and +6, EMBO J., 16, 2482-2492.

Kozak, M. (2002). Pushing the limits of the scanning mechanism for initiation of translation, Gene, 299, 1-34.

Liu, X., Wang, X., Shen, Y., Wu, L., Ruan, X., Lindpaintner, K., Yusuf, S., Engert, J. C., Anand, S., Tan, X., Liu, L. (2009). The functional variant rs 1048990 in PSMA6 is associated with susceptibility to myocardial infarction in a Chinese population. Atherosclerosis, 206(1), 199-203.

Maksymowych, W.P., Russel, A.S. (1995). Polymorphism in the LMP2 gene influences the relative risk for acute anterior uveitis in unselected patients with ankylosing spondylitis. J. Clin. Invest., 18, 42-46.

Maksymowych, W.P., Tao, S., Luong, M., Suarez-Almazor, M., Nelson, R., Pazderka, F., Russell, A.S. (1995). Polymorphism in the LMP2 and LMP7 genes and adult rheumatoid arthritis: No relationship with disease susceptibility or outcome. Tissue Antigens, 46, 136-139.

Naujokat, C., Hofman, S. (2002). Role and function of the 26S proteasome in proliferation and apoptosis. Lab. Invest., 82, 965-980.

Ozaki, K., Sato, H., Iida, A., Mizuno, H., Nakamura, T., Miyamoto, Y., Takahashi, A., Tsunoda, T., Ikegawa, S., Kamatani, N., Hori, M., Nakamura, Y., Tanaka, T. (2006). A functional SNP in PSMA6 confers risk of myocardial infarction in the Japanese population. Nat. Genet., 38, 921-925.

Petty, R.E., Southwood, T.R., Manners, P., Baum, J., Glass, D.N., Goldenberg, J., Xiaohu, H., Maldonado-Cocco, J., Orozco-Alcala, J., Prieur, A.M., Suarez-Almazor, M.E., Woo, P. (2001). International League of Association for Rheumatology Classification of Juvenile Idiopathic Arthritis: Second Revision, Edmonton. J. Rheumatol., 31, 2-3.

Prahalad, S., Kingsbury, D.J., Griffin, T.A., Cooper, B.L., Glass, D.N., Maksymowych ,W.P., Colbert, R.A. (2001). Polymorphism in the MHC-encoded LMP7 gene: Association with JRA without functional significance for immunoproteasome assembly. J. Rheumatol., 28, 2320-2325.

Pryhuber, K.G., Murray, K.J., Donnelly, P., Passo, M.H., Maksymowych, W.P., Glass, D.N., Giannini, E.H., Colbert, R.A. (1996). Polymorphism in the LMP2 gene influences disease susceptibility and severity in HLA-B27 associated juvenile rheumatoid arthritis. J. Rheumatol., 23, 747-752.

Robbesyn, F., Garcia, V., Auge, N., Vieira, O., Frisach, M.F., Salvayre, R., Negre-Salvayre, A. (2003). HDL counterbalance the proinflammatory effect of oxidized LDL by inhibiting intracellular reactive oxygen species rise, proteasome activation, and subsequent NF-kappaB activation in smooth muscle cells. FASEB J., 17(6), 743-745.

Sjakste, N., Sjakste, T., Rumba, I., Vikmanis, U. (2002a). Proteasomes in pathology. Proc. Latv. Acad. Sci. B, 56(1/2), 7-16.

Sjakste, N., Sjakste, T., Vikmanis, U. (2002b). Role of the ubiquitinproteasome protein degradation pathway in carcinogenesis, tumor progression and susceptibility to tumor treatment. Exp. Oncol., 24, 243-248.

Sjakste, T., Eglite, J., Sochnev, A., Marga, M., Pirags, V., Collan, Y., Sjakste, N. (2004). Microsatellite genotyping of chromosome $14 q 13.2-14 q 13$ in the vicinity of proteasomal gene PSMA6 and association with Graves' disease in the Latvian population. Immunogenetics, 56, 238-243.

Sjakste, T., Kalis, M., Poudziunas, I., Pirags, V., Lazdins, M., Groop, L. \& Sjakste, N. (2007a). Association of microsatellite polymorphisms of the human $14 \mathrm{q} 13.2$ region with type 2 diabetes mellitus in Latvian and Finnish populations. Ann. Hum. Genet., 71, 772-776.

Sjakste, T., Poudziunas, I., Ninio, E., Perret, C., Pirags, V., Nicaud, V., Lazdins, M., Evans, A., Morrison, C., Cambien, F., Sjakste N. (2007b). 
SNPs of PSMA6 gene - investigation of possible association with myocardial infarction and type 2 diabetes mellitus. Russ. J. Genet., 43, 442-448.

Sjakste, T., Lauberte, L., Collan, Y., Savontaus, M.L., Bajare, A., Scherrer, K., Sjakste, N. (2002c). Identification of an intronic TG repeat polymorphism in the human proteasome core particle PROS-27K gene. DNA Seq., 13(3), 139-144.

Sjakste, T.G., Sjakste, N.I., Scherrer., K. (2001). Exon/Intron Organisation of Pros-27 K Gene. DNA Seq., 12(4), 261-265.

Takashima, N., Shioji, K., Kokubo, Y., Okayama, A., Goto, Y., Nonogi, H., Iwai, N. (2007). Validation of the Association Between the Gene Encoding Proteasome Subunit $\alpha$ Type 6 and Myocardial Infarction in a Japanese Population. Circ. J., 71, 495-498.

Thompson, S.D., Moroldo, M.B., Guyer, L., Ryan, M., Tombragel, E.M., Shear, E.S., Prahalad, S., Sudman, M., Keddache, M.A., Brown, W.M, Giannini, E.H., Langefeld, C.D., Rich, S.S., Nichols, W.C., Glass, D.N.
(2004). A genome-wide scan for juvenile rheumatoid arthritis in affected sibpair families provides evidence of linkage. Arthritis Rheum., 50, 2920-2930.

Vieira, O., Escargueil-Blanc, I., Jürgens, G., Borner, C., Almeida, L., Salavayre, R., Salvayre, A.N. (2000). LDLs alter the activity of the ubiquitin-proteasome pathway: Potential role in oxidized LDL-induced apoptosis. FASEB J., 14(3), 532-542.

Wenzel, T., Elssner, T., Fahr, K., Bimmler, J., Richter, S., Thomas, I., Kostrzewa, M. (2003) Genosnip: SNP genotyping by MALDI-TOF MS using photocleavable oligonucleotides. Nucleosides Nucleotides Nucleic Acids, 22(5-8), 1579-1581.

Wilson, S.H., Simari, R.D., Lerman, A. (2001) The effect of endothelin-1 on nuclear factor kappa B in macrophages. Biochem. Biophys. Res. Commun., 286, 968-972.

Received 11 July 2009

\section{ASOCIĀCIJU PĒTĪJUMS STARP 14q11 - 14q13 PROTEASOMU GĒNU KLASTERA ĢENĒTISKIEM VARIANTIEM UN JUVENĪLO IDIOPĀTISKO ARTRĪTU (JIA) LATVIJAS POPULĀCIJĀ.}

Hipotēze par iespējamo proteasomu lomu autoimūno slimību attīstībā tika izvirzīta pēc protasomālo subvienību LMP2 un LMP7 līdzdalības atklāšanas antigēnu prezentācijā. Pētījuma mērkis bija pārbaudīt iespējamo asociāciju starp proteasomālo proteīnu gēnu PSME1, PSME2 un PSMA6 alēlu variantiem un juvenīlo idiopātisko artrītu (JIA) Latvijas populācijā. Viens insercijas/delēcijas polimorfisms $\mathrm{G}^{-4543} \mathrm{CA}^{-4544} \rightarrow \mathrm{GA}$ un četri viena nukleotīda polimorfismi $P S M A 6$ gēnā un tā apkārtnē $\left(\mathrm{A}^{-2486} \rightarrow \mathrm{G}\right.$ un $\mathrm{C}^{-1910} \rightarrow \mathrm{T}$ augšup no promotera,

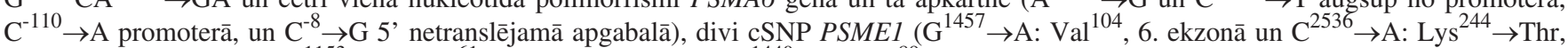
11.ekzonā) un PSME2 $\left(\mathrm{C}^{1153} \rightarrow \mathrm{G}: \mathrm{Arg}^{61} \rightarrow \mathrm{Gly}\right.$, 4. ekzonā un $\mathrm{A}^{1440} \rightarrow \mathrm{C}: \mathrm{His}^{89} \rightarrow$ Pro, 6. ekzonā) tika genotipēti, izmantojot specifisku praimeru PCR, restrikcijas vietas polimorfismu un/vai sekvencēšanu gadījumu/kontroles pētījumā 156 JIA slimniekos un 214 veselos indivīdos. Alēḷu biežums un genotipu sadale bija vienādas kontroles un slimnieku grupās PSMA6 insercijas/delēcijas polimorfisma un viena nukleotīda polimorfismu: $\mathrm{A}^{-2486} \rightarrow \mathrm{G}, \mathrm{C}^{-1910} \rightarrow \mathrm{T}$ un $\mathrm{C}^{-8} \rightarrow \mathrm{G}$, gadījumos, kā arī visu pētīto PSME1 un PSME2 gēnu cSNP gadījumos. Atsevišķi analizējot atškirības $\mathrm{A}^{-110}$ alēles un $\mathrm{CG}$ genotipu biežumos starp slimnieku un kontroles grupām, tās bija tuvas statistiskai ticamībai, $P$ vērtība nedaudz pārsniedza 0.05 , aditīvā model̦a izmantošana pierādīja, ka visam $\mathrm{C}^{-110} \rightarrow \mathrm{G}$ lokusam šīs atškirinibas ir statistiski ticamas. Mūsu rezultāti atbalsta hipotēzi par iespējamo PSMA6 gēna alēlu asociāciju ar JIA Latvijas populācijā. 